\title{
Manus da og nå - forfatterveiledningen like viktig
}

Kravene til innsendelse av manus har forandret seg gjennom tidene, og det samme har produksjonsmåten. Men redaksjonen har hele veien prøvd å bistå forfatterne med råd og hjelp.

Et innlegg i Tidsskriftet fra 1922 om innsending av manus er publisert i spalten Tidligere i Tidsskriftet i 2004 (1). Der ble forfatterne instruert om hvor viktig det var å skrive tydelig.

«Til våre ærede innsendere og medarbeidere! Da det ofte mottas manuskripter, som er utydelige, tildels meget utydelig skrevet, - da mange er skrevet på blokklapper eller med blyant etc., ønsker vi gjerne å innprente nedenstående regler.» Så følger instruks om å skrive med maskin, eventuelt for hånd med blekk, ikke med blyant, på blokkpapir, ikke på smålapper og bruke korrekt skrivemåte for medisinske termer, personnavn og andre egennavn. I det siste punktet ble det presisert at «Forandringer i den i «Tidsskriftet» benyttede ortografi maa ikke foretages». De fleste rådene var utførlig begrunnet $\mathrm{i}$ hensynet til produksjon og kostnader.

\section{Forfatterveiledningenes varighet} Teksten kan kalle på smilet i dag, men rådene var viktige den gang. Det var nok tidkrevende å sende inn korrekt skrevne manus når man ikke kunne skrive i vei og rette og slette på data. Interessant nok sto den samme teksten på trykk i 1933, så store forandringer kom ikke så ofte (2).

\section{Endringene skyter fart}

Siden 2004 har Tidsskriftet hatt elektronisk manuskriptbehandlingssystem. Også her finnes retningslinjer til hjelp for brukerne (3). Man blir loset gjennom alle stegene, enten man er forfatter, vurderer eller har andre roller.

Nylig er vår forfatterveiledning oppdatert og er blitt mer brukervennlig (4). Her finnes bl.a. oversikter over artikkeltyper, manusutforming, etikk og jus, informasjon om forfatterskap, rettigheter og interessekonflikter.

\section{Språkspørsmål like aktuelt}

Her finnes også et eget avsnitt om språk. Leserne og forfatterne har alltid vært veldig opptatt av språket som formidlingsverktøy. Ortografiske spørsmål debatteres like iherdig. Tidsskriftets ordliste ligger i Forfatterveiledningen under et eget punkt om språk (5).

Tidsskrift for

Den norske legeforening

\section{Forfatterveiledning for Tidsskriftet}

$$
\begin{aligned}
& \text { I forfatterveiledningen finner } \\
& \text { du viktig informasjon som du } \\
& \text { trenger før innsending av } \\
& \text { manuskriptet til Tidsskriftet. }
\end{aligned}
$$

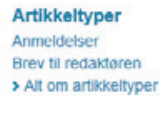

Hepogonger Hjelp og kontakt Kontaktinformasjon tII
redaksjonen Levere manus $>$ At om hjelp og kontak

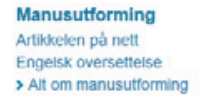

Etlikk og jus Anonymisering og informert samtykke Dobbellpublisering Sprák Generelle sprákràd atinske og greske ord og uttrykk Att om sprá
Erfaren forfatter Sjekkliste for manusutforming og levering.

\section{Fersk forfatter}

Hjelp til manusutforming og levering.
Fagvurderer

Hensikten med fagvurdering er faglig kvalitetssikring.

\section{Noe dere savner?}

Vi vet at Forfatterveiledningen er til nytte for våre forfattere og at den benyttes hyppig. Vi håper på tilbakemelding til redaksjonen om noe skulle være uklart eller om det er temaer som burde vært omtalt. Forfatterveiledningen er hele tiden under utvikling.

\section{Raida Ødegaard}

raida.oedegaard@legeforeningen.no Tidsskriftet

Raida Ødegaard (f. 1946) er filolog og manusredaktøri Tidsskriftet.

Ingen oppgitte interessekonflikter.
Litteratur

Hem E. Forfatterveiledning anno 1922. Tidsskr No Lægeforen 2004; 124: 2859.

2. Om innsendte artiklers optagelse i «Tidsskriftet». Tidsskr Nor Lægeforen 1933; 53: 160.

3. ScolarOne Manuscripts. http://mc manuscriptcentral.com/tidsskriftet (13.10.2011).

4. Forfatterveiledning for Tidsskriftet. http:// tidsskriftet.no/Innhold/Forfatterveiledningen (13.10.2011).

5. Ordliste. http://tidsskriftet.no/Innhold/ Forfatterveiledningen/Spraak/Ordliste (13.10.2011).

Mottatt 17.10. 2011 og godkjent 19.10. 2011 Medisinsk redaktør Erlend Hem. 